\title{
生理食塩水の追加投与はロピバカインによる 硬膜外麻酔後の運動神経ブロック回復時間を短縮する
}

$\begin{array}{lll}\text { 島崎晆久* } & \text { 立川真弓 } & \text { 榎本澄江* } \\ \text { 奥田圭子 } & \text { 新井丈郎* } & \text { 奥田泰久* }\end{array}$

[要旨] 硬膜外麻酔は全身麻酔と比較してさまざまな利点があるが, 欠点として不必要な麻酔効果 の残存があげられる. 今回われわれは経尿道的膀胱腫瘍切除手術症例に0.75\%ロピバカインを用 いた持続硬膜外麻酔を施行し, 手術終了時に硬膜外カテーテルを抜去する直前に生理食塩水を追加 投与した群と, 追加投与しなかった群で運動神経ブロックの回復時間を比較した. その結果, 生理 食塩水追加投与群は運動神経ブロックの回復時間が有意に短かった.

キーワード：局所麻酔薬，硬膜外麻酔，分離麻酔，生理食塩水，生理食塩水追加投与

\section{はじめに}

長時間作用性局所麻酔薬であるロピバカインは短 時間作用性局所麻酔薬であるリドカインなどと比較 して神経毒性が低く, また同じ長時間作用性局所麻 酔薬であるブピバカインと比較して心毒性および中 枢神経毒性が低いために安全性が高い薬剤とされて いる ${ }^{1) \sim 4}$.さらに運動神経より感覚神経をより強く ブロックする可能性が指摘されており，運動機能を 保持しながら鎮痛効果が期待できるために最近は硬 膜外麻酔に多用されている ${ }^{1) \sim 4)}$. しかしながら投与 する部位，濃度，量および個々の患者の感受性の違 いから，時に運動神経も長時間にわたつてブロック されることがある.遅延する運動神経のブロックは, 深部静脈血栓症や末梢神経障害の予防, 消化管の機 能促進などのための早期離床を妨げ，術後の末梢神 経機能評価の支障となり, 患者の満足度ならびに外
受理日 2011. 2. 23. 採択日 2012.4.9.
科医の信頼度を低下させることにつながる。ささに 日帰り手術などにおいては回復室や病室での長期滞 在は医療経済の面から好ましいことではない。これ までに局所麻酔薬を使用した硬膜外麻酔の効果を拮 抗させる手段はなく，投与した各局所麻酔薬の作用 が自然に消失するまで待たなければならなかった。

近年，局所麻酔薬を用いた硬膜外麻酔後に生理食 塩水を硬膜外腔へ追加投与することにより，麻酔作 用時間が変化するとの研究 ${ }^{5) ~ 10)}$ がある。臨床的意義

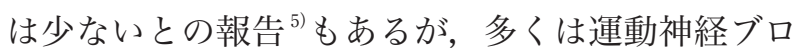
ックからの回復時間が短縮したとの研究結果であ $3^{6) \sim 10)}$. 短時間作用性局所麻酔薬であるリドカイン やメピバカインの作用時間をさらに短縮することの 臨床的有用性はあまり高くないと考えられるが7 10), 長時間作用性局所麻酔薬であるブピバカインを用い た硬膜外麻酔においても同様に生理食塩水の追加投 与が運動神経ブロックからの回復時間を短縮したと 
報告されている ${ }^{6)}$. 今回われわれは硬膜外麻酔に多 用されているロピバカインについて, 手術終了時に 追加投与した生理食塩水が運動神経ブロックの回復 時間を短縮するか否かを検討した。

\section{I 対象と方法}

本研究は著者が所属する施設の倫理委員会の承認 を得て実施した。経尿道的膀胱腫瘍切除術を予定さ れたASA I またはIIの患者のうち，本研究につい て承諾を得た 67 症例を対象とした。麻酔前投薬は 投与しなかった。硬膜外麻酔は左側臥位で L3〜 L5 から 17 ゲージ Tuohy 針(ペリカン ${ }^{\circledR}$, ビー・ブラウ ンエースクラップ社, 東京)を正中アプローチによ り穿刺し, 生理食塩水を用いた抵抗消失法で硬膜外 腔を確認した。頭側に $5 \mathrm{~cm}$ カテーテルを挿入し， 血液および髄液のカテーテルからの逆流がないこと を確認後に $1 \%$ リドカイン $2 \mathrm{~mL}$ を用いた試験投与を 行った。カテーテルが春髄くも膜下に位置していな いことを 5 分後に確認し $0.75 \%$ ロピバカイン $10 \mathrm{~mL}$ を注入し， 20 分後に cold testで麻酔高がTh10 以上 で手術可能と判断された症例のみを研究対象とし た。麻酔高がTh11以下の場合や術中に鎮痛補助薬 を必要とした症例は除外した。担当麻酔科医の判断 で術中の循環動態維持のために必要に応じて昇圧薬 投与および輸液負荷を行った。手術終了時に症例を 無作為に2 群に分け, カテーテルから生理食塩水 $20 \mathrm{~mL}$ 緩徐に投与後カテーテルを抜去した群(生 食群) と，生理食塩水を投与せず，カテーテルをそ のまま抜去した群(対照群)とに割り付けた。患者割 り付けを知らされていない検者により, 手術終了時 から 1 時間ごとに下肢の運動神経ブロックを評価し た。評価方法はBromage scale ${ }^{11)}$ (Scale 0：膝や足 を十分に動かすことが可能, Scale 1 : 膝を動かす ことが可能, Scale 2:足首だけを動かすことが可能, Scale 3: 膝も足首も動かすことが不可能)を用いて 行い, Scale 0になるまで評価を続けた。下肢の Bromage scaleに左右差がある場合はScale值の高
い方を記録した。

$<$ 統計処理 $>$

当施設での過去の結果から， 0.75\%ロピバカイン $10 \mathrm{~mL}$ の硬膜外腔投与後の運動麻痺はおよそ 4 時間 (標準偏差 1 時間)であった。生理的食塩水の投与に より，麻痺時間が 2 割短縮，すなわち約 50 分 $(240$ 分 $\times 0.2)$ 短縮できれば臨床的に意味のある差と考え

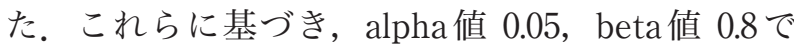
パワー分析をすると, 各グループで 30 人が必要で あった。運動神経遮断時間は対応のないt検定を用 い, Bromage scale 值はFisher's exact testを用い, 結果は中央值と範囲で表し，P<0.05をもって統計 学的に有意差ありとした。

\section{II 結 果}

対象になった 67 症例中 7 症例が研究から除外さ れた。研究対象となった 60 症例の患者背景を表 1 に示す。2群間の年齢，身長，体重，手術時間，麻 酔時間，性および手術終了時の麻酔高，総輸液量に 差はなかった。

手術終了時において両群において Bromage scale に差はなかったが，2時間後から有意差が現れ， Scale 0 になるまでの平均時間は，生食群で $144 \pm$ 7.4 分, 対照群で $250 \pm 10.4$ 分であり, 生理食塩水 投与により運動神経ブロックからの回復時間が有意 に短縮 $(42 \%$ 減少) した $(P<0.05)$ (表 2，図 1)。下肢 の運動神経ブロックの左右差は生食群で 30 症例中 15 症例, 対照群で 30 症例中 13 症例において認めら れた。全対象において副作用は出現しなかった。

\section{III 考 察}

硬膜外麻酔に使用する局所麻酔薬の量や濃度は患 者の身長，体重，年齢および術式を考慮して決定す べきとされている ．外科手術に際して全身麻酔と の併用ではなく硬膜外麻酔単独で対応する場合は, 鎮痛のみならず術野の不動化や筋弛緩を得るため に, 通常 $0.5 \sim 0.75 \%$ のピバカインが用いられる ${ }^{3)}$. 
表 1 両群の患者背景

\begin{tabular}{lcc}
\hline & 生食群 & 対照群 \\
\hline 症例数 & 30 & 30 \\
平均年齢(歳) & $67.1 \pm 2.2$ & $67.0 \pm 2.2$ \\
平均身長 $(\mathrm{cm})$ & $162.0 \pm 1.7$ & $163.2 \pm 1.9$ \\
平均体重 $(\mathrm{kg})$ & $63.1 \pm 2.1$ & $62.6 \pm 2.0$ \\
手術時間 $($ 分) & $44.7 \pm 1.2$ & $44.9 \pm 1.3$ \\
麻酔時間 (分) & $67.9 \pm 6.1$ & $67.4 \pm 7.3$ \\
男女比(男 $/$ 女) & $26 / 4$ & $25 / 5$ \\
麻酔高 $($ 手術終了時) & Th8 \pm 1.9 & Th8 \pm 2.2 \\
術中輸液量 $(\mathrm{mL})$ & $473.3 \pm 147.2$ & $463.3 \pm 124.5$ \\
\hline mean $\pm \mathrm{SD}$ & &
\end{tabular}

ロピバカインの初回投与量については, 下半身の手 術に対して十分な麻酔高を得るためには $20 \mathrm{~mL}$ が必 要であると報告されている ${ }^{12)}$.しかしながら，われ われは経験的に, 局所麻酔薬の必要量がより少ない 高齢者患者での経尿道的膀胱腫瘍切除術に対しては $10 \mathrm{~mL}$ の投与で手術可能であると考えている。もち ろん追加投与を施行する症例もあるが，必要以上の 局所麻酔薬の投与は低血圧や合併症発生の危険性を 増加させると考えている. 生理食塩水によって感覚 神経ブロックの回復時間が短縮されるとしても，オ ピオイドを局所麻酔薬に加えていれば術後鎮痛は保 持できるとの報告 ${ }^{10)} も$ ある。

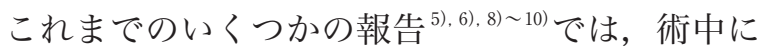
一定の麻酔高を得るための局所麻酔薬を追加投与し ている。われわれは投与した局所麻酔薬も結果に影 響すると考え，ロピバカインの投与時間と投与量を 一定にして研究を行った。

次に生理食塩水の投与時期については, 局所麻酔 薬の最終投与から一定時間後に投与している報 告 ${ }^{5)}$ 9) もあるが，われわれは患者の安全性について の倫理的観点から, 他の報告 ${ }^{6) ~ 8), ~ 10) ~}$ と同様に, 手術 終了時に生理食塩水を投与した。

生理食塩水の投与量については，これまでの報告 では $20 \sim 90 \mathrm{~mL}^{5) \sim 10)}$ とさまざまで $20 \mathrm{~mL}$ 以下では無 効だったとの報告 ${ }^{9}$ もある. より多くの生理食塩水
表2 術後の経時的 Bromage Scale (中央値と範囲)

\begin{tabular}{cc}
\hline 測定時間 & Bromage Scale \\
\hline 手術直後 & $2(1-3)$ \\
1 時間後 & $2(1-3)$ \\
2 時間後 & $2(1-3)$ \\
3 時間後 & $1(0-2)$ \\
\hline
\end{tabular}

を投与すれば麻酔作用の消失効果がより促進される かもしれないが, その場合は脳脊髄圧上昇, 頭痛, 背部痛，筋攣縮などの副作用を引き起こす可能性も あるため, 本研究では過去の報告 ${ }^{7)}$ も参考にして $20 \mathrm{~mL}$ とした。その結果, $20 \mathrm{~mL} て ゙$ 運動神経ブロ ックからの回復が促進された。 より多くの生理食塩 水投与を勧女る報告 ${ }^{5), 6), 8) ~ 10) ~}$ 異なる結果となった 理由は, 使用した局所麻酔薬の種類の差あるいは高 齢者が対象であったことが考えられる。

硬膜外腔に投与された局所麻酔薬がどのような機 序で麻酔作用を発現し, 消失していくのかの詳細は いまだ不明である。推測される麻酔作用発現の機序 は，硬膜外腔へ投与された薬物は春髄神経根が春髄 神経に移行する部位の硬膜を浸透して脊髄神経根へ 作用し, さらに硬膜を通過してくも膜下へ移行して 作用を発揮することである。また作用消失機序は, 投与された薬物の椎間孔からの漏出や, 神経・脂肪・ 軟部組織に拡散した後の血管・リンパ管への吸収な 


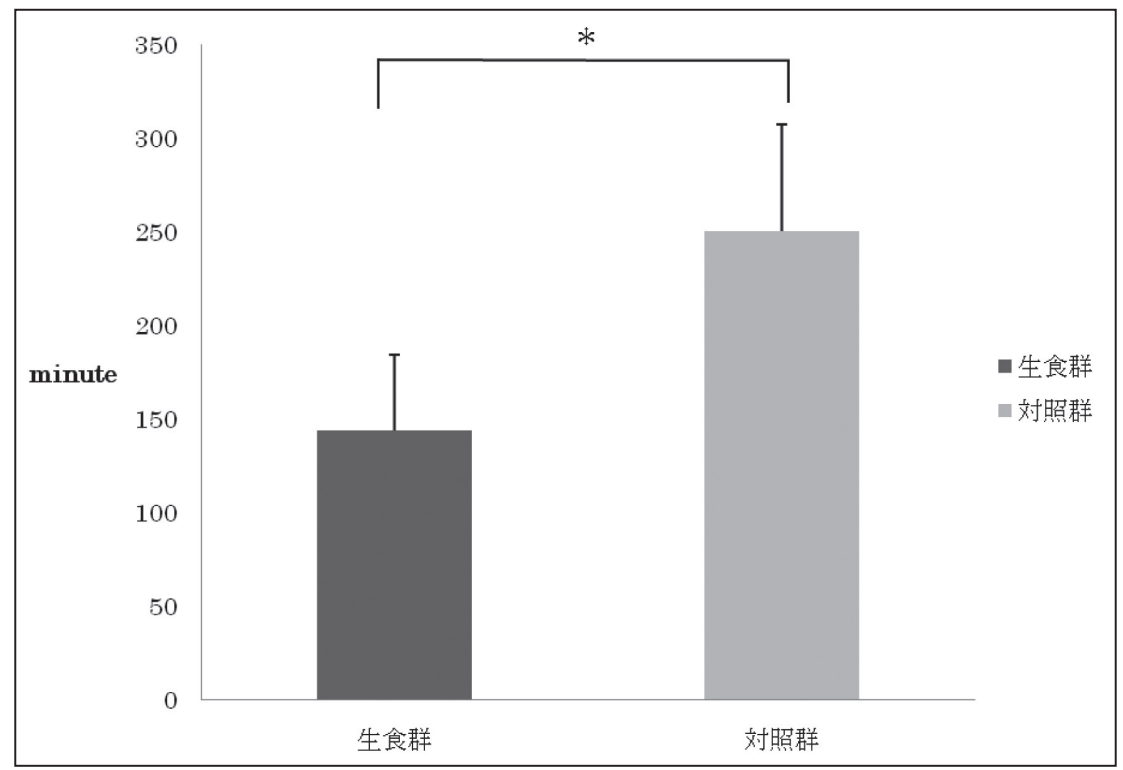

図 1 運動神経ブロックからの回復時間

Bromage scaleが 0 になるまでの時間は, 生食群で $144 \pm 7.4$ 分, 対照群で $250 \pm 10.4$ 分であった。 mean $\pm \mathrm{SD} \quad * P<0.05$

どが考えられている ${ }^{13)}$.

生理食塩水の硬膜外への追加投与がどのような機 序で局所麻酔の作用時間を短縮するかも詳細は不明 であり，推測されるものを表 3 に示す。例えば硬膜 外腔が薬液貯蔵所の役割を果たしていると仮定する と, 貯蔵された局所麻酔薬が追加投与された生理食 塩水により希釈されて作用部位へなんらかの影響を 与えていると推測される ${ }^{8)}$. また生理食塩水の投与 により局所麻酔薬の血管からの吸収が促進される可 能性については, その時の血中の局所麻酔薬濃度は

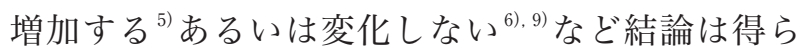
れていない. 投与した生理食塩水が局所麻酔薬の作 用に重要な $\mathrm{pH}$ を酸性に変化させて効果を減弱させ

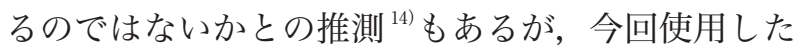
$0.75 \%$ ロピバカイン(アナペイン ${ }^{\circledR}$ 注 $7.5 \mathrm{mg} / \mathrm{mL}, \mathrm{pH}$ $=4 \sim 6$, アストラゼネカ)に生理食塩水(生食注 $20 \mathrm{~mL}, \mathrm{pH} \fallingdotseq 6$, 大塚製薬)が大きな影響を与えた とは考元難い。

本研究では運動神経ブロックの変化の評価のみを
施行し，感覚神経のブロック(麻酔高)の変化につい ては評価を行わなかった。これまでの報告では生理 食塩水の追加投与により運動神経ブロックの回復時 間の短縮はほぼ一定しているが，感覚神経ブロック については回復時間は短縮するとの報告 ${ }^{5)}{ }^{8)}$, 9), 回 復時間は短縮するが運動神経ブロックほどではない との報告 ${ }^{10)}$, 回復時間は短縮しないとの報告 ${ }^{6)}{ }^{77}$ が あり一定していない，最近は電位依存性 $\mathrm{Na}$ チャネ ルのサブタイプでの考方方があり，神経線維の大小 のみで局所麻酔薬の効果発現についての議論はでき ないかもしれないが，細い感覚神経は，太い運動神 経よりも低濃度の局所麻酔薬によって容易にブロッ クされる ${ }^{15)}$. 硬膜外腔の局所麻酔薬は追加投与され た生理食塩水により希釈され濃度が低下するはずで ある。その結果，薄められた局所麻酔薬は運動神経 ブロック可能な濃度以下に容易に低下するが，かつ 感覚神経をブロック可能な濃度以上に留まることが 考えられる。その濃度の局所麻酔薬は投与された生 理食塩水により押し流されて硬膜外腔での分布範囲 


\section{表 3 生理食塩水が運動神経ブロックからの回復を促 進する仮説 ${ }^{5)}$ 10)}

1) 硬膜外腔で神経に直接作用している局所麻酔薬が生理食 塩水により洗い流される ${ }^{6)}$

2) 硬膜外腔の局所麻酔薬が追加投与された生理食塩水によ り希棌されて効果が減弱する ${ }^{5), 6), 8) ~ 10) ~}$

3）硬膜外腔の局所麻酔薬が生理食塩水により椎間孔から押 し流される ${ }^{5}$

4) 生理食塩水の追加投与により局所麻醉薬の硬膜外腔での 上下の拡がりが大きくなり, 硬膜外腔での脂肪組織, リ ンパ組織および静脈叢からの吸収面積が拡大して, 局所 麻醉薬の硬膜外腔からの消失が促進される ${ }^{6), 8)}$

5) 生理食塩水が局所麻酔薬の作用する $\mathrm{pH}$ に变化を与えて 麻酔効果を減弱させる ${ }^{6) \sim 8)}$

6) 生理食塩水投与により春髄液の産生および吸収が促進さ れ，それに伴ってくも膜下に拡散して作用していた局所 麻酔薬が減少する 5 , 7)

(麻酔範囲)がさらに拡大することが感覚神経ブロッ クの結果を一定させない原因と推測されている ${ }^{8)}$. 0.75\%ロピバカインを用いた硬膜外麻酔で手術終 了時に追加投与した生理食塩水により, 運動神経ブ ロックからの回復時間が短縮した。長時間作用性局 所麻酔薬を用いた硬膜外麻酔において, 術後の不必 要な麻酔時間の短縮やなんらかの理由で緊急に麻酔 作用を消失させることが必要となった場合に，硬膜 外腔への生理食塩水の追加投与は有用な手段である.

本稿の要旨は日本臨床麻酔学会第 31 回大会 (2011, 沖縄)において発表した。

\section{参考文献}

1) Peduto VA, Baroncini S, Montanini S, et al. : A prospective, randomized, double-blind comparison of epidural levobupivacaine $0.5 \%$ with epidural ropivacaine $0.75 \%$ for lower limb procedures. Eur J Anaesthesiol $20: 979-983,2003$

2) Leone S, Di Cianni S, Casati A, et al. : Pharmacology, toxicology, and clinical use of new long acting local anesthetics, ropivacaine and levobupivacaine. Acta
Biomed $79:$ 92-105, 2008

3）小田裕：ロピバカインの薬物動態と毒性. 日臨麻会誌 $29: 519-527,2009$

4）新山幸俊, 川股知之：婦人科・泌尿器科手術における ロピバカインの臨床使用の実際. 日臨麻会誌 $29: 683-$ 689, 2009

5) Rodríguez J, Rodríguez V, Naveira A, et al. : Epidural washout with high volumes of saline to accelerate recovery from epidural anaesthesia. Acta Anaesthesiol Scand $45: 893-898,2001$

6) Johnson MD, Burger GA, Mushlin PS, et al. : Reversal of bupivacaine epidural anesthesia by intermittent epidural injections of crystalloid solutions. Anesth Analg $70: 395-399,1990$

7) Brock-Utne JG, Macario A, Dillingham MF, et al. : Postoperative epidural injection of saline can shorten postanesthesia care unit time for knee arthroscopy patients. Reg Anesth Pain Med 23 : 247-251, 1998

8) Sitzman BT, DiFazio CA, Playfair PA, et al. : Reversal of lidocaine with epinephrine epidural anesthesia using epidural saline washout. Reg Anesth Pain Med 26 : 246-251, 2001

9) Chan VW, Nazarnia S, Kaszas Z, et al. : The impact of saline flush of the epidural catheter on resolution of epidural anesthesia in volunteers : a dose-response study. Anesth Analg 89 : 1006-1010, 1999

10) Park EY, Kil HK, Park WS, et al. : Effect of epidural saline washout on regression of sensory and motor block after epidural anaesthesia with $2 \%$ lidocaine and fentanyl in elderly patients. Anaesthesia $64: 273-276$, 2009

11) Bromage PR : Mechanism of action, Epidural Analgesia. Edited by Bromage PR. WB Saunders, Philadelphia, 1978, 119-159

12）大澤正巳, 鈴木太, 吉矢生人ほか：塩酸ロピバカイン (NA-001)の臨床的研究 長時間作用性局所麻酔薬 塩 酸ロピバカイン $(\mathrm{NA}-001) 5 \mathrm{mg} / \mathrm{ml}$ 扩よび $7.5 \mathrm{mg} / \mathrm{ml}$ 注 射液の硬膜外麻酔における用量の検討 第 II 相試験. 臨 床医薬 $15 ： 1101-1116,1999$

13）西邑信男，小倉忍：硬膜外麻酔の作用機序. LiSA 2 : 14-17, 1995

14）松本美志也：局所麻酔薬総論. 日臨麻会誌 $28: 723-$ 731, 2008

15) Gissen AJ, Covino BG, Gregus J : Differential sensitivities of mammalian nerve fibers to local anesthetic agents. Anesthesiology $53: 467-474,1980$ 


\title{
Additional Epidural Injection of Saline Can Shorten Postoperative Motor Blockade after Ropivacaine Epidural Anesthesia
}

\author{
Mutsuhisa SHIMAZAKI, Mayumi TACHIKAWA, Sumie ENOMOTO, \\ Keiko OKUDA, Takero ARAI, Yasuhisa OKUDA \\ Department of Anesthesiology, Dokkyo Medical University, Koshigaya Hospital
}

Although epidural anesthesia has several advantages over general anesthesia, it has the disadvantage of prolonged postoperative recovery for motor function. We evaluated whether $20 \mathrm{~mL}$ of saline injected epidurally on removal of the catheter shortened the motor recovery from epidural ropivacaine anesthesia. Sixty patients who underwent transurethral surgery received lumbar epidural anesthesia with $10 \mathrm{~mL}$ of ropivacaine. At the end of surgery, the patients were randomly allocated to two groups, and $20 \mathrm{~mL}$ saline was injected epidurally in one group, whereas the other group was given none, upon removal of an epidural catheter. The motor block was assessed with the Bromage scale. The time to recovery of motor function in the saline group was significantly shorter (144 min)than in the control group (250 $\mathrm{min})$. We believe that epidural injection of saline would be useful to shorten postoperative motor blockade.

Key Words : Local anesthetic drug, Epidural anesthesia, Differential nerve block, Saline, Additional saline injection

The Journal of Japan Society for Clinical Anesthesia Vol.32 No.5, 2012 